\title{
International Experience Reference and Mathematical Statistics Analysis of China's Free Trade Zone Construction
}

\author{
Zhang Rui \\ Xi'an Eurasia University, Shaanxi, China, 710000
}

Keywords: China's free trade area; statistical index system; analytic hierarchy process

\begin{abstract}
Under the new " $1+3+7$ " free trade zone pattern, the research on the statistical index system of the free trade area has a far-reaching research prospect in the construction of China's free trade area. But so far, the research on the design and construction of the statistical index system of the free trade area is still insufficient. By constructing a small and sophisticated statistical index evaluation system for China's free trade area, this paper elaborates on the practical application process of the AHP evaluation index system in China's free trade area, and provides some references for the statistical index system of China's free trade area.
\end{abstract}

\section{Introduction}

At present, under the general trend of rapid development in the free trade area, China urgently needs to develop an innovative statistical index system to enable it to objectively and scientifically evaluate the strategy of the Free Trade Zone in the context of constructing a new type of open economic system. In order to achieve the interconnection between the innovative statistical indicator system of the FTA and the statistical system of Jinpu New District and achieve horizontal comparison with the other 10 FTAs in China, the international mainstream statistical indicator system has been integrated to achieve international comparison. This paper aims at strategic positioning and builds The basic statistical index system and characteristic statistical index system reflecting the China Free Trade Zone [1].

This article will carry out comprehensive refinement on the basis of the statistical indicators system of the major domestic and foreign free trade zones, and combine the index system theory in international comparison with the policies, construction goals and development prospects of the free trade zone, and use the analytic hierarchy process to set Index weights have been built to cover innovative and multi-level statistical indicators systems covering investment and trade facilitation, financial innovation and government environmental supervision, and the soft power of free trade zones.

\section{Foundation of Innovative Statistical Index System in China's Free Trade Area}

Due to differences in the positioning and types of different countries' free trade areas, it is necessary to construct a statistical index system that is universal and comparable to the Free Trade 
Area, and it is necessary to screen from the existing and official statistical indicators. The commercial environment assessment system has this feature. However, WB's evaluation index system is based on the national level, and many of these indicators do not apply to the statistical indicator system evaluation at the regional level [2]. Therefore, the statistical index system for a regional level needs to be redesigned.

The comprehensive development evaluation index system constructed by the China Statistical Institute has been promoted nationwide for several years, and it is both powerful and practical. So this article as one of the main references. On this basis, perfecting improvement and refining innovation are the research directions for establishing an innovative statistical index system in the FTA. The statistical index system of the free trade zone must be systematically described, measured and evaluated in accordance with the relevant regulations, norms or standards of the national and local governments. When constructing the statistical index system of the pilot area for free trade, in addition to considering the full-scale description, it must also be able to highlight this feature and advantage of the Free Trade Zone [3]. The Institute of Free Trade of Shanghai University of Finance and Economics has carried out third-party assessment work for the existing four major free trade areas (Shanghai, Tianjin, Guangzhou and Fujian), and has accordingly proposed a set of evaluation indicators for China's free trade area.

\begin{tabular}{|c|c|}
\hline \multicolumn{2}{|c|}{$t$-Test 1(Blot A) } \\
\hline wild type & mut $y$ \\
\hline 150 & 400 \\
200 & 600 \\
100 & 500 \\
\hline $\bar{x}=150$ & $\bar{x}=500$ \\
\hline SD $=50.0$ & SD $=100$ \\
\hline SEM $=28.9$ & SEM $=57.2$ \\
\hline \multicolumn{2}{|c|}{$P=0.013$} \\
\hline
\end{tabular}

\begin{tabular}{|c|c|}
\hline \multicolumn{2}{|c|}{$t$-Test 2 (Blot B) } \\
\hline wild type & mut $y$ \\
\hline 70 & 240 \\
50 & 150 \\
80 & 290 \\
\hline $\bar{x}=66.7$ & $\bar{x}=227$ \\
\hline SD $=15.7$ & SD $=71.0$ \\
\hline SEM $=8.82$ & SEM $=41.0$ \\
\hline \multicolumn{2}{|c|}{$P=0.054$}
\end{tabular}

\begin{tabular}{|c|c|}
\hline \multicolumn{2}{|c|}{$t$-Test 3 (Blot C) } \\
\hline wild type & mut $y$ \\
\hline 300 & 690 \\
220 & 980 \\
330 & 440 \\
\hline $\bar{x}=283$ & $\bar{x}=703$ \\
\hline SD $=56.9$ & SD $=270$ \\
\hline SEM $=32.8$ & SEM $=156$ \\
\hline \multicolumn{2}{|c|}{$P=0.11$} \\
\end{tabular}

Fig.1 Statistical Analysis of Test 1 to Test 3

This study combines the statistical indicators announced by various existing FTAs in China, the comprehensive development evaluation index system announced by the China Statistics Association, the third-party evaluation index system of major FTAs in China, and the global business environment assessment system announced by the World Bank. On this basis, we will refine, integrate, improve, and innovate, and construct an innovative statistical index system for China's free trade area, ensuring the orientation, forward-lookingness, openness, operability, recognition, and international comparability of selected indicators. in principle.

\section{Constructions and Evaluation of Innovative Statistical Index System in China's Free Trade Zone}

\subsection{AHP-Based Comparative Matrix Setting of Basic Statistics Indicator System in China's Free Trade Zone}

To evaluate the statistical index system of China's free trade area, we must first compare the impact of the first-level indicators on the statistical index system of China's free trade area, and construct a pair comparison matrix. Among the five first-level indicators identified in the basic statistical index system of the China Free Trade Zone, we believe:

Compared with public assessment indicators, the indicators of scientific and technological innovation and ecological construction are somewhat important, social development indicators are more important, and economic development indicators are strongly important; they are relative to 
ecological construction indicators and technological innovations. In terms of indicators, social development indicators are somewhat important and economic development indicators are more important; relative to social development indicators, economic development indicators are somewhat important. Based on the same method, the description of the importance of each related secondary index and the tertiary indicators[3]. Using the special analytical hierarchy process software yaahp to solve the above comparison matrix, calculate the weights of the indicators of each level, the elements of the secondary indicators relative to the related elements of the primary indicators, and the elements of the tertiary indicators relative to the secondary indicators The weights and total weights of the elements associated with them.

\begin{tabular}{|c|c|c|c|}
\hline \multicolumn{4}{|c|}{ Cl calculations for ratios } \\
\hline & Ratio (mut y/wt) & $95 \% \mathrm{Cl}$ & $99 \% \mathrm{Cl}$ \\
\hline Blot 1 & 3.33 & $1.87-4.80$ & $1.41-5.26$ \\
\hline Blot 2 & 3.41 & $1.91-4.90$ & $1.44-5.37$ \\
\hline Blot 3 & 2.48 & $1.27-3.70$ & $0.882-4.09$ \\
\hline Lanes 1 & 2.56 & $0.0990-5.02$ & ND \\
\hline Lanes 2 & 3.68 & $-0.230-7.58$ & ND \\
\hline Lanes 3 & 2.41 & $0.0682-4.76$ & ND \\
\hline All data & 2.85 & $1.34-4.37$ & $0.863-4.85$ \\
\hline
\end{tabular}

Fig.2 Comparison of total data analysis

\subsection{AHP-Based Evaluation of the Basic Statistics Indicator System in China's Free Trade Area}

The weight of each indicator is shown in Figure 1. The weights of the first-level indicators in the basic statistical indicator system of the China Free Trade Zone are as follows: economic development index 0.5011; social development index 0.2461; ecological construction index 0.1038; scientific and technological innovation index 0.1038; public evaluation index 0.0453 . In addition, the largest eigenvalue corresponding to the weight vector is:

$$
\lambda \max =5.1264
$$

Conduct a consistency check on it to obtain:

$$
\mathrm{CR}=0.0282<0.1
$$

So pass the consistency test. For the second-level indicators, the six secondary indicators of the economic development indicators are relative to the development quality indicators $(0.031)$ and the industry development indicators (0.060) are slightly more important. The fiscal and taxation indicators (0.144) and the structural optimization indicators (0.135) are Importantly, foreign economic and trade indicators (0.269) and economic growth indicators (0.362) are very important; among the five secondary indicators of social development indicators, social security (0.053) is slightly more important than regional coordination (0.0307). Public service expenditure (0.246), cultural education (0.114), and health (0.109) are important, and income distribution $(0.448)$ is very important. Similarly, according to expert evaluations, the relative importance of three-level indicators can be ranked. Among the three-level indicators, the economic index's foreign economic and trade import and export value (0.637) ranked first, the per capita GDP (0.426) ranked second, the urban and rural residents' income of the social development index accounted for the proportion of GDP (0.5) and Gina. The coefficient (0.5) ranked third and fourth. This is in line with the fact that China's free trade area has focused on promoting foreign trade and local attention to the quality of life of residents. 


\section{Summary}

As far as the characteristic index system of the China Free Trade Zone is concerned, the degree of opening up and innovation of the service industry in China is still relatively low, and the government still has excessive intervention in the micro-behavior of the market and enterprises, which has obviously affected the level of China's free trade area construction. Promote. Vigorously promote the further opening up of China's free trade zone service industry, and in the process of opening up, speed up the reform of the administrative system of the Free Trade Zone, try to simplify administrative decentralization, reduce the interference in the company's micro-behavior, and expand its development experience to Throughout the country, to maximize the promotion of the construction of a free trade pilot zone with international standards of investment and trade facilitation, efficient and convenient supervision, and standardized legal environment.

\section{References}

[1] Xiao L, Zhou G, Guo A. Effectiveness Analysis of China(Shanghai)Pilot Free Trade Zone after One-year Construction[J]. Scientific Development, 2015.

[2] Zhang S K, Yun H E. Analysis of the Reform Orientation and Construction Policy of China Pilot Free Trade Zone[J]. Journal of Shaanxi Academy of Governance, 2017.

[3] Li H E. Practices of Coastal and Inland Free Trade Zones in South America and China's Free Trade Zone Construction[J]. International Business Research, 2014. 